\title{
The Incomplete Story of Fasting in Ramadan and Raised Serum Lipids
}

\author{
S. M. Bakir, M.B.Ch.B., M.Sc., Ph.D. \\ Riyadh, Saudi Arabia
}

DOI: http://dx.doi.org/10.5915/23-2-15073

\begin{abstract}
Despite only scanty research on the effects of fasting in Ramadän, a few researchers have suggested that there is an increase in serum lipids while fasting during the month of Ramadân. Furthermore, concerns have been raised about the possible adverse effects of fasting on serum lipids. In this article some explanations are provided for the probable causes of raised lipids during fasting in Ramadain.
\end{abstract}

Key words: Fasting, Ramaḍān, serum lipids

Fasting in Ramadān is one of the five pillars of Islam. It means abstinence from food and drink from dawn to sunset, averaging about 15 hours daily for one lunar month.

Ideally, breaking the fast at sunset, includes eating a few dates and drinking some water or yogurt. Later, a medium size meal is taken, or preferably small size meals are consumed at intervals during the night. The last meal "Suhür" is consumed just before "Fajr" (dawn) prayer. This practice is what the Prophet $(\mathrm{PBUH})$ was reported to have done.

Unfortunately, some fasters consume large amounts of food once they break their fast at sunset by eating one large meal.

From the Department of Physiology College of Medicine, King Saud University Riyadh, Saudi Arabia.

\section{Reprint Requests:}

Dr. S.M. Bakir, M.B.Ch.B., M.Sc., Ph.D. Department of Physiology, College of Medicine King Saud University

Riyadh, P.O. Box 2925

Saudi Arabia.
Some researchers have observed an increase in serum lipids during Ramadãn fasting, ${ }^{1-3}$ and have concluded that such changes could have adverse effects on health. ${ }^{1,3}$

\section{Discussion}

In a previously published review article, ${ }^{4}$ it was suggested that the factors of meal frequency and dietary composition could be responsible for the raised serum lipids during Ramaḍan fast. In this article more light is shed on these factors.

Cohn et al in $1965^{5}$ studied two groups of rats. One group was allowed to eat ad libitum, while the second group was fed an identical quantity of food by stomach tube twice a day. At the end of the study, the body fat content in the tube-fed rats was twice as high as in the animals which were fed ad libitum.

In 1964, Cohn ${ }^{6}$ showed that normal human volunteers who ate several small meals a day, had lower concentrations of cholesterol than when the same total intake was taken in a few large meals. This finding was later confirmed by others. ${ }^{7-9}$ They studied college students fed isocaloric diets containing the same foods consumed either in one, three or six meals per day. The serum cholesterol of the students in the single meal program was $366 \mathrm{mg} / \mathrm{dl}$ compared to 260 and $267 \mathrm{mg} / \mathrm{dl}$ respectively for sub- 
jects from the groups fed three and six meals.

As regards the dietary composition, a number of studies have stressed its importance on measured serum lipids. Heaton and Pomare, ${ }^{10}$ and Trowell ${ }^{11}$ have shown that serum triglycerides and cholesterol were lower in people who have a high intake of dietary fiber. Mancini et al ${ }^{12}$ showed that LDL and VLDL were significantly reduced in twenty eight hyperlipidemic patients when treated with a diet low in saturated fat and cholesterol.

The association between these animal and human studies, and Ramadān fasting, was shown by Frost and Pirani's study in $1987 .{ }^{13}$ This work showed that during Ramadān fast there is a significant reduction in meal frequency and a significant increase in caloric intake.

From the above disucssion, it appears that the increase in serum lipids is probably not due to fasting itself, as the previous reports have suggested, ${ }^{1-3}$ but rather is a consequence of decreased meal frequency and overeating when people break their fast. One possible mechanism for the raised serum lipids could be that the net flux of free fatty acids from the fat depots due to prolonged periods of fasting, is increased in those who consume one large meal per day. This would result in increased synthesis of serum lipids by the liver due to the increased uptake of free fatty acids. ${ }^{14}$

It seems that we are in fact examining two distinct nutritional stages; a stage of total deprivation from food and drink for about fifteen hours, and a stage of overeating from sunset till dawn.

This hypothesis about the effect of fasting on serum lipids needs to be verified by further controlled animal and human trials.

\section{Acknowledgement}

I would like to express my thanks to Mr. Nazeer Khan of CMRC for searching the literature, and $\mathrm{Mr}$. Mohammad Akram for typing.

\section{References}

1. Fedail SS, Murphy D, Salih SY, Bolton $\mathrm{CH}$, Harvey RF: Changes in certain blood constituents during Ramadan. Am J Clin Nutr 1982;36:350-3.
2. Hazmi MAF, El-Faleh F, Al-Mofleh I. Effect of Ramadan Fasting on the values of Haematological and Biochemical Parameters. Saudi Med J 1987;8:171-6.

3. Shoukry, MI: Effects of Fasting in Ramadan on Plasma Lipoproteins and Apoproteins. Saudi Med J 1986;7:561-5.

4. Bakir SM: Fasting in Ramadan. JIMA 1989;21:180-2.

5. Cohn C, Joseph D, Bell L, Allweiss MD: Studies on the effects of feeding frequency and dietary compostion on fat deposition. N Y Acad Sc 1965;131:507-18.

6. Cohn C: Feeding patterns and some aspects of cholesterol metabolism. Fed Proc 1964;23:76-81.

7. Irwin IM, Feeley RM: Frequency and size of meals and serum lipids, nitrogen and mineral retention, fat digestability and urinary thiamine and riboflavin in young women. Am J Clin Nutr 1967;20:816-24.

8. Young CM, Scanlan SS, Topping CM, Simkov V, Lutwak L: Frequency of feeding, weight reduction and body composition. J Am Diet Assoc 1971;59:466-72.

9. Young CM, Hutter LF, Scanlan SS, Rand CE et al: Metabolic effects of meal frequency on normal young men. J Am Diet Assoc 1972;61:391-8.

10. Heaton KW, Pomare EW: Bran and blood lipids. Lancet 1974;315, 49-50.

11. Trowell H: Definition of dietary fiber and hypothesis that it is a protective factor in certain disorders. Am J Clin Nutr 1976;29:417-27.

12. Mancini M, Rubba A, Postiglone C, Iovine C, Faunaro E, and Lamenza F: Changes in Plasma lipoprotein concentration in patients with marked hyperlipidemia on lipid lowering diet. In: Noseda G, Lesis B,Paeletti R, eds, "Diet and drugs in atherosclerosis." New York: Raven Press 1980.

13. Frost G, Pirani S: Meal frequency and nutritional intake during Ramadan: A pilot study. Human Nutrition: Applied Nutrition, (1987).

14. Gwinup GR, Byron RC, Roush WH, Kruger FA, and Hamwi GJ: Effect of nibbling versus gorging on serum lipids in man. Am J Clin Nuti 1963;13:209-13. 